\title{
Ketersediaan Sarana dan Prasarana Pendidikan Jasmani, Olahraga dan Kesehatan
}

\author{
I Gede Oki Hendriadi ${ }^{1 *}$ \\ ${ }^{1}$ Jurusan Pendidikan Olahraga, Universitas Pendidikan Ganesha, Singaraja, Indonesia
}

\section{ARTICLE INFO \\ Article history: \\ Received January 05, 2021 \\ Revised January 09, 2021 \\ Accepted June 07, 2021 \\ Available online July 25, 2021}

Kata Kunci:

Sarana, Prasarana, PJOK

Keywords:

Facilities, Infrastructure, PJOK

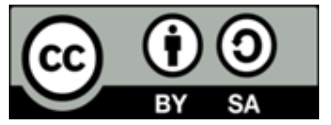

This is an open access article under the CC BY-SA license.

Copyright $(\subseteq 2021$ by Author. Published by Universitas Pendidikan Ganesha.

\begin{abstract}
A B S T R A K
Penelitian ini dilakukan atas dasar permasalahan yang ditemui di lapangan yaitu mengenai sarana dan prasarana pembelajaran di sekolah yang masih kurang. Penelitian ini bertujuan untuk mengetahui ketersedian sarana dan prasarana Pendidikan Jasmani, Olahraga dan Kesehatan (PJOK) pada SMA/SMK Negeri se-Kecamatan Pekutatan Kabupaten Jembrana. Penelitian ini merupakan penelitian deskriptif menggunakan metode survei. Yang menjadi subjek penelitian adalah SMA Negeri 1 Pekutatan dan SMK Negeri 5 Negara. Analisis data menggunakan teknik deskriptif analisis atau menggambarkan secara detail hasil penelitian yang diperoleh. Berdasarkan data yang diperoleh, dapat dipaparkan bahwa ketersediaan sarana dan prasarana PJOK di SMA Negeri 1 Pekutatan mendapat skor total sebesar 130, Sementara ituuntuk ketersediaan sarana dan prasarana PJOK di SMK Negeri 5 Negara mendapatkan total skor sebesar 90. Dengan hasil tersebut maka ketersedian sarana dan prasarana PJOK pada SMA/SMK Negeri seKecamatan Pekutatan Kabupaten Jembrana masuk ke dalam kategori Cukup "C". Disarankan bagi guru PJOK, sekolah dan pemerintah untuk selalu memperhatikan dan juga melengkapi sarana dan prasarana secara berkelanjutan agar proses pembelajaran dapat berjalan dengan optimal.
\end{abstract}

\begin{abstract}
ABST RAK
This research was conducted on the basis of the problems encountered in the field, namely the lack of learning facilities and infrastructure in schools. This study aims to determine the availability of facilities and infrastructure for Physical Education, Sports and Health (PJOK) in public high schools/vocational schools throughout Pekutatan District, Jembrana Regency. This research is a descriptive research using survey method. The research subjects were SMA Negeri 1 Pekutatan and SMK Negeri 5 Negara. Data analysis used descriptive analysis techniques or described in detail the research results obtained. Based on the data obtained, it can be explained that the availability of PJOK facilities and infrastructure at SMA Negeri 1 Pekutatan got a total score of 130, Meanwhile for the availability of PJOK facilities and infrastructure at SMK Negeri 5 Negara got a total score of 90. With these results, the availability of facilities and infrastructure PJOK at state high schools / vocational schools throughout the Pekutatan District, Jembrana Regency is included in the " $C$ " Enough category. It is recommended for PJOK teachers, schools and the government to always pay attention and also equip facilities and infrastructure on an ongoing basis so that the learning process can run optimally.
\end{abstract}

\section{PENDAHULUAN}

Belajar merupakan suatu aktivitas yang dilakukan dimanapun dan sepanjang hayat (Mulya \& Lengkana, 2020; Wiraguna, Lanang, Parwata, \& Semarayasa, 2020). Pembelajaran adalah suatu proses belajar yang diselenggarakan oleh guru untuk membelajarkan siswa dalam memperoleh pengetahuan, keterampilan dan sikap" (Dimyati \& Mudjiono,2013). Pada hakikatnya proses pembelajaran adalah suatu proses interaksi yang terjadi dua arus atau hubungan timbal balik antara guru, peserta didik dan antara sesama peserta didik dalam satuan pembelajaran dengan mendambakan hasil belajar yang optimal (Arimbawa, Astra, \& Satyawan, 2017). Pembelajaran merupakan suatu proses kegiatan aktif dan 
dilakukan secara sadar oleh guru dan peserta didik yang ditunjukkan dengan timbulnya perubahan peserta didik dari tidak tahu menjadi tahu dan perubahan perilaku secara permanen atau tetap (D. Bete, 2019) . Perubahan ini berdasarkan pengalaman yang bersifat positif yang meliputi perubahan cara berpikir (kognitif), tingkah laku (afektif), dan gerak (psikomotor) yang sesuai dengan PJOK (Nurjanah \& Mulyana, 2019).

PJOK merupakan proses pendidikan yang memanfaatkan aktivitas fisik dan kesehatan untuk menghasilkan perubahan holistik baik dalam hal fisik, mental, serta emosional (Indrawathi, et al., 2021; (Khikmah, 2019). Keberhasilan pelaksanaan pembelajaran PJOK dapat diukur dari keberhasilan peserta didik yang mengikuti pembelajaran tersebut. Keberhasilan dapat dilihat dari tingkat pemahaman, penguasaan materi dan hasil belajar peserta didik. PJOK merupakan suatu proses pembelajaran melalui aktivitas jasmani, dimana dalam setiap proses pembelajarannya bertujuan untuk meningkatkan kemampuan pengetahuan, keterampilan, dan prilaku hidup sehat (Pambudi et al., 2019; Risandy et al., 2020; Sugiarto, 2019). PJOK merupakan suatu proses seseorang sebagai individu maupun anggota masyarakat yang dilakukan secara sadar dan sistematik melalui berbagai kegiatan dalam rangka memperoleh kemampuan dan keterampilan jasmani, pertumbuhan, kecerdasan, dan pembentukan watak (Sulaksono \& Wibowo, 2021). PJOK memliki sebuah tujuan dalam tumbuh kembangnya tingkat kebugaran jasmani manusia yang berhubungan dengan keterampilan gerak, berfikir kritis, keterampilan aspek sosial, penalaran, stabilitas emosi, sikap moral, dalam perlakuan hidup sehat, pemahaman sebuah lingkungan bersih dalam aspek aktivitas jasmani (Herlina \& Suherman, 2020; Sudibyo\& Nugroho, 2020; Wicaksono, 2019).

Tujuan utama PJOK adalah meningkatkan life-long physical activity dan mendorong perkembangan fisik, psikologis dan sosial peserta didik. Selain itu, PJOK bertujuan melatih gerak motorik dan menjaga kesehatan jasmani maupun rohani (Cahyati \& Hariyanto, 2019). Tujuan ini mendorong perkembangan motivasi diri untuk melakukan aktivitas fisik, memperkuat konsep diri, belajar bertanggung jawab dan keterampian kerjasama. Pada dasarnya, siswa membutuhkan suatu dorongan dalam mencapai keberhasilan pada kegiatan pembelajaran (Pasaribu \& Mashuri, 2019). Keberhasilan peserta didik dalam mengikuti proses pembelajaran dipengaruhi oleh dua faktor yaitu faktor internal dan eksternal (Qoulbi \& Alnedral, 2020). Didalam pembelajaran PJOK, faktor internal memiliki peran yang sangat penting dalam menentukan keberhasilan proses pembelajaran karena faktor internal itu berasal dari dalam diri peserta didik. Faktor eksternal juga dapat memberikan dampak yang sangat besar untuk dapat membantu tercapainya keberhasilan proses pembelajaran, dalam hal ini yang dikatakan sebagai bagian dari faktor eksternal meliputi sarana dan prasarana PJOK itu sendiri.

Kebutuhan sarana dan prasrana pendidikan jasmani menjadi hal yang sangat vital dan sangat berpengaruh terhadap keberhasilan pembelajaran (Herman\& Riady, 2018; Natal \& Bate, 2020; Rohmah et al., 2020). Sarana dan prasarana memberikan manfaat yang banyak dalam proses pembelajaran (Jordan, 2019; Junaedi \& Wisnu, 2015). Kurangnya sarana dan prasarana penunjang pembelajaran disekolah akan menghambat proses pembelajaran sehingga akan berpengaruh pada hasil akhir pembelajaran (Hanggara, 2019; Nugraha \& Nurharsono, 2020). Dalam pembelajaran PJOK, sarana dan prasarana memiliki manfaat yang signifikan terhadap keberhasilan suatu proses pembelajaran di sekolah. Sarana mengandung arti sesuatu yang dapat digunakan atau dapat dimanfaatkan. Sarana pendidikan jasmani ialah segala sesuatu yang dapat digunakan atau dimanfaatkan di dalam pembelajaran pendidikan jasmani dan kesehatan. Sarana olahraga dikelompokan menjadi dua kelompok yaitu (1) peralatan merupakan sesuatu yang digunakan, contohnya palang tunggal, palang sejajar, gelang-gelang, kuda-kuda dan lain-lain (2) Perlengkapan merupakan sesuatu yang melengkapi kebutuhan prasarana, misalnya net, bola, raket dan lai-lain (Asad, Mulyadi., \& Sugiharto, 2020). Sarana olahraga sangat berperan penting pada saat proses pembelajaran berlangsung. Sekolah, guru atau bahkan peserta didik akan merasa terbantu apabila keberadaan sarana olahraga memadai disetiap sekolah, dengan demikian proses pembelajaran dan hasil belajar PJOK peserta didik akan lebih optimal. Prasarana adalah segala sesuatu yang merupakan penunjang utama terselenggaranya produksi/kegiatan. Prasarana merupakan sumber penunjang yang terdiri atas tempat olahraga berupa bangunan yang memenuhi kriteria pelaksanaan kegiatan olahraga. Prasarana digunakan sebagai sesuatu yang mempermudah atau memperlancar tugas dan memiliki sifat yang relatif permanen. Salah satu sifat dari prasarana adalah susah dipindahkan Suryobroto (dalam Satyawan, 2014). Dari pemaparan tersebut dapat disimpulkan bahwa prasarana adalah segala fasilitas yang menunjang suatu proses atau kegiatan. Sementara itu prasarana PJOK adalah segala fasilitas yang dapat digunakan untuk melakukan kegiatan olahraga. Sementara itu prasarana atau tempat berolahraga adalah ruang terbuka atau tertutup yang dilengkapi dengan sarana untuk melakukan pendidikan jasmani dan olahraga. Maka dapat disimpulkan sarana dan prasana PJOK merupakan alat bantu yang digunakan dalam proses pembelajaran PJOK guna menciptakan hasil belajar yang optimal. Ketersediaan sarana dan prasarana yang memadai akan sangat berpengaruh terhadap kesiapan, motivasi serta hasil belajar siswa. 
Namun pada kenyataannnya berdasarkan hasil observasi yang dilakukan, peneliti menemukan beberapa masalah yang ada di sekolah, salah satu masalah terbesar dari proses pembelajaran PJOK adalah mengenai keberadaan sarana dan prasarana penunjang pembelajaran PJOK di sekolah. Pengadaan sarana dan prasarana masih mengalami kekurangan (Arham, 2019). Masih terbatasanya sarana dan prasarana yang tersedia disekolah sehingga menyulitkan guru dalam proses mengajar, guru cenderung menggunakan metode ceramah dan hanya memperagakan gerakan dengan sarana dan prasarana yang tersedia, hal tersebut berdampak terhadap motivasi siswa dalam mengikuti kegiatan olahraga. Terbatasnya lahan untuk melakukan proses pembelajaran pendidikan jasmani, hal ini sangat berdampak terhadap minat serta motivasi siswa terhadap pembelajran PJOK, sehingga bila minat dan motivasi siswa rendah dalam belajar akan berpengruh terhadap hasil belajarnya.

Untuk mengetahui ketersediaan sarana dan prasarana yang tersedia di sma/smk negeri sekecamatan pekutatan kabupaten jembrana maka dilakukan survei ketersediaan sarana dan prasarana pendidikan jasmani, olahraga dan kesehatan. Penelitian ini didukung oleh beberapa penelitian sebelumnya yaitu 1) penelitian oleh (Hadi, 2013) menunjukan bahwa kondisi penjasorkes pada satuan pendidikan SD, SMP, SMA Negeri di Kecamatan Karangan mendapat nilai 615,81 masuk kategori “B”(baik). 2) penelitian oleh (Yusuf, 2016) yang menunjukkan bahwa kondisi tingkat kemajuan pendidikan jasmani, olahraga, dan kesehatan di SMA Negeri se-Kabupaten Bangkalan termasuk kategori "C" atau cukup dengan nilai rerata 560. 3) penelitian oleh (Anggriawan, 2018) (Anggriawan S., \&Fajar, 2018) yang mengemukakan rata-rata ketersediaan sarana dan prasarana yang ada di SMP se-Kecematan Kebomas Kab. Gresik, sebesar 58 \% mendapatkan kategori C (cukup). Penelitian mengenai survei terhadap sarana dan prasarana pembelajaran pendidikan jasmani telah diteliti di berbagai tempat dengan hasil yang bervariasi. Adapun hal yang membedakan antara penelitian ini dengan penelitian sebelumnya yakni penelitian ini melakukan survei sarana dan prasarana pembelajaran PJOK pada pada jenjang SMA negeri se-kecamatan pekutatan kabupaten jembrana. Tujuan penelitian ini yakni untuk mengetahui ketersedian sarana dan prasarana Pendidikan Jasmani, Olahraga dan Kesehatan (PJOK) pada SMA negeri se-kecamatan Pekutatan Kabupaten Jembrana.

\section{METODE}

Jenis penelitian yang digunakan pada penelitian ini adalah penelitian deskriptif. Penelitian deskriptif yang digunakan pada penelitian ini adalah dengan metode survei dengan mengisi lembar observasi sebagai intrumen pengumpulan datanya. Tujuan dilakukan survei adalah untuk melihat secara langsung keberadaan sarana dan prasarana yang ada disekolah. Dalam penelitian ini yang menjadi subjek penelitian adalah seluruh SMA/SMK Negeri se-Kecamatan Pekutatan. Jumlah SMA/SMK Negeri seKecamatan Pekutatan adalah sebanyak 2 sekolah yaitu SMA Negeri 1 Pekutatan dan SMK Negeri 5 Negara. Instrumen yang digunakan dalam penelitian ini berpedoman pada intrumen Pangkalan Data Pendidikan Jasmani, Olahraga Indonesia (PDPJOI). Pengumpulan data dilakukan dengan wawancara, observasi langsung dan dokumentasi.Pada penelitian ini pendekatan yang digunakan adalah deskriptif analisis. Deskriptif analisis bersifat menggambarkan hasil penelitian yang dilakukan. Prosedur pelaksanaan penelitian ini yang pertama kali dilakukan adalah menentukan subjek penelitian, selanjutnya meminta ijin kepada kepala sekolah dan guru PJOK dimasing-masing sekolah untuk melakukan sebuah penelitian, setelah mendapatkan ijin, peneliti melakukan wawancara dengan guru PJOK terkait dengan sarana dan prasarana PJOK, kemudian melakukan observasi langsung sembari mengisi lembar observasi yang sudah disiapkan. Selama melakukan wawancara dan observasi pada saat melakukan penelitian, peneliti juga melakukan dokumentasi untuk memperkuat atau membuktikan penelitian disaat peneliti sedang mengambil data. Setelah data terkumpul barulah data tersebut dijabarkan menggunakan teknik deskriptif analisis.

\section{HASIL DAN PEMBAHASAN}

Pada saat pengambilan data dimasing-masing sekolah, SMA/SMK se-Kecamatan Pekutatan Kabupaten Jembrana diperoleh hasil yang berbeda-beda. Data yang diperoleh meliputi jumlah sarana dan prasarana, kualifikasi (standar/tidak) prasarana PJOK serta kondisi (rusak/layak) sarana PJOK.. Untuk lebih mudah memahami mengenai jumlah sarana dan prasarana PJOK di SMA/SMK Negeri se-Kecamatan Pekutatan Kabupaten Jembrana, dapat dilihat pada Tabel 1 dibawah:

Tabel 1. Jumlah sarana dan prasarana di SMA/SMK Negeri se-Kecamatan Pekutatan Kabupaten Jembrana

\begin{tabular}{cccc}
\hline Nama Sekolah & Sarana & Prasarana & Total \\
\hline SMA Negeri 1 Pekutatan & 144 & 11 & 155 \\
SMK Negeri 5 Negara & 97 & 6 & 113 \\
\hline
\end{tabular}


Tabel 1 menunjukkan data sarana dan prasarana yang ada di SMA Negeri 1 Pekutatan dan SMK Negeri 5 Negara. Masing-masing memiliki jumah sarana dan prasarana yang berbeda. Untuk mengetahui sarana yang ada dalam suatu sekolah maka peneliti melakukan kualifikasi pada masing-masing sekolah. Berikut ini kualifikasi prasarana di SMA Negeri 1 Pekutatan akan disajikan pada Tebl 2 berikut.

Tabel 2. Kualifikasi Prasarana di SMA Negeri 1 Pekutatan

\begin{tabular}{cccc}
\hline \multirow{2}{*}{ Prasarana } & \multicolumn{3}{c}{ SMA N 1 Pekutatan } \\
\cline { 2 - 3 } & Ada/Tidak & Standar & Tidak \\
\hline Atletik & Ada & $\checkmark$ & $\checkmark$ \\
Akuatik & Tidak & & $\checkmark$ \\
Sepak Bola & Tidak & $\checkmark$ & $\checkmark$ \\
Bolavoli & Ada & $\checkmark$ & $\checkmark$ \\
Bola Basket & Ada & & $\checkmark$ \\
Beladiri & Ada & $\checkmark$ & $\checkmark$ \\
Bulutangkis & Tidak & & $\checkmark$ \\
Tenis Meja & Ada & & \\
Sepak Takraw & Tidak & &
\end{tabular}

Dari Tabel 2, dapat dilihat bahwa hanya prasarana atletik, bolavoli, bolabasket, dan tenis meja saja yang ada di SMA Negeri 1 Pekutatan dan masuk dalam kualifikasi standar, sementara untuk lapangan sepak bola, SMA Negeri 1. Pekutatan masih meminjam lapangan milik desa/pemerintah, namun lapangan tersebut belum masuk dalam kualifikasi standar. Untuk prasarana bulutangkis, SMA Negeri 1 Pekutatan menggunakan lapangan milik pemerintah karena disekolah belum tersedia lapangan bulutangkis. Sementara itu untuk prasarana akuatik SMA Negeri 1 Pekutatan masih belum memilikinya. Untuk kualifikasi prasarana di SMK 5 Negara disajikan pada Tabel 3 berikut ini.

Tabel 3. Kualifikasi prasarana di SMK Negeri 5 Negara

\begin{tabular}{cccc}
\hline \multirow{2}{*}{ Prasarana } & & SMK N 5 Negara & Tidak \\
\cline { 2 - 4 } & Ada/Tidak & $\checkmark$ & $\checkmark$ \\
Atletik & Ada & & $\checkmark$ \\
Aktik & Tidak & & $\checkmark$ \\
Sepak Bola & Ada & $\checkmark$ & $\checkmark$ \\
Bolavoli & Ada & $\checkmark$ & $\checkmark$ \\
Beladiri & Ada & $\checkmark$ & \\
Bulutangkis & Tidak & & $\checkmark$ \\
Tenis Meja & Ada & $\checkmark$ & \\
Sepak Takraw & Ada & & \\
\hline
\end{tabular}

Dari Tabel 3, dapat dijabarkan bahwa hanya prasarana akuatik dan beladiri saja yang tidak dimiliki oleh SMK Negeri 5 Negara. Sementara untuk prasarana sepak bola dan tenis meja sudah dimiliki oleh SMK Negeri 5 Negara namun masih belum masuk pada kualifikasi standar karena prasarana yang dimiliki dalam kondisi rusak. Prasarana atletik, bolavoli, bola, basket, bulutangkis dan sepak takraw sudah dimiliki oleh SMK Negeri 5 Negara dan sudah masuk dalam kualifikasi standar. Sementara itu hasil penelitian mengenai kondisi sarana dimasing-masing sekolah juga memiliki perbedaan. Untuk lebih jelasnya dapat dilihat pada Tabel 4 berikut.

Tabel 4. Total skor kondisi sarana dimasing-masing sekolah

\begin{tabular}{|c|c|c|c|}
\hline \multirow[t]{2}{*}{ Nama sekolah } & \multicolumn{2}{|c|}{ Jumlah } & \multirow[t]{2}{*}{ Total } \\
\hline & Layak & Rusak & \\
\hline SMA Negeri 1 Pekutatan & 125 & 19 & 144 \\
\hline SMK Negeri 5 Negara & 82 & 15 & 97 \\
\hline
\end{tabular}

Dari Tabel 4, dapat simpulkan bahwa jumlah sarana dimasing-masing sekolah berbeda-beda. Di SMA Negeri 1 Pekutatan terdapat sebanyak 144 sarana dengan rincian sebanyak 19 sarana dalam kondisi rusak dan 125 sarana masih dalam kondisi yang layak. Sementara itu di SMK Negeri 5 Negara terdapat 97 sarana dengan rincian sebanyak15 sarana kondisinya rusak dan 82 sarana lainnya masih dalam kondisi 
yang layak. Dengan hasil tersebut maka didapatkan total skor untuk menentukan kategori skor mengenai ketersedian sarana dan prasarana PJOK di SMA/SMK Negeri se-Kecamatan Pekutatan Kabupaten Jembrana. Untuk lebih jelasnya disajikan kedalam Tabel 5 berikut:

Tabel 5. Total skor ketersediaan sarana dan prasarana di sekolah

\begin{tabular}{ccccccc}
\hline Nama & \multicolumn{2}{c}{ Jumlah Sarana } & \multicolumn{2}{c}{ Jumlah Prasarana } & Total skor \\
\cline { 2 - 5 } sekolah & Layak & Rusak & Standar & Tidak & \\
\hline SMA N 1 Pekutatan & 125 & 19 & 5 & 1 & 130 \\
SMK N 5 Negara & 82 & 1 & 5 & 8 & 3 & 90 \\
\hline \multicolumn{7}{c}{ Rata-rata skor } \\
\hline \multicolumn{7}{c}{}
\end{tabular}

$\begin{array}{lr}\begin{array}{l}\text { Skala Perhitungan } \\ \text { Layak/Standar }\end{array} & : \text { skor 1 } \\ \begin{array}{l}\text { Rusak/Tidak } \\ \text { Rata-rata skor }\end{array} & : \text { skor 0 } \\ & \text { : skor S } \\ \text { Kategori penilaian } & \\ \text { Istimewa (A) } & : 220 \text { keatas } \\ \text { Baik (B) } & : 165-219 \\ \text { Cukup(C) } & : 110-164 \\ \text { Kurang (D) } & : 55-109 \\ \text { Kurang Sekali (E) } & : 0-54\end{array}$

Sesuai dengan total skor pada Tabel 5 dan mengacu pada kategori penilaian maka ketersediaan sarana dan prasarana PJOK di SMA Negeri 1 Pekutatan masuk dalam Kategori Cukup "C" dengan total skor 130, sementara ketersediaan sarana dan prasarana PJOK di SMK Negeri 5 Negara masuk dalam kategori kurang "D" dengan total skor 90. Dengan hasil tersebut maka ketersedian sarana dan prasarana PJOK pada SMA/SMK Negeri se-Kecamatan Pekutatan Kabupaten Jembrana masuk ke dalam kategori Cukup "C" dengan mendapatkan skor rata-rata sebesar 110. Berdasarkan hasil penelitian yang telah diuraikan yang membahas 3 pokok bahasan yaitu mengenai jumlah sarana dan prasarana, kualifikasi (standar/tidak) prasarana PJOK serta kondisi (rusak/layak) sarana PJOK. Dari 2 SMA/SMK Negeri se-Kecamatan Pekutatan Kabupaten Jembrana yang menjadi subjek penelitian, terdapat beberapa sarana yang tidak ada di sekolah dan terdapat juga beberapa sarana yang dimiliki namun dalam kondisi tidak layak/rusak.

Kondisi sarana PJOK didua sekolah yang menjadi subjek penelitian sangat berbeda. Di SMA Negeri 1 Pekutatan terdapat 19 sarana yang dalam kondisi rusak dan 125 sarana masih dalam kondisi yang layak dari jumlah total 144 sarana. Sementara itu di SMK Negeri 5 Negara terdapat 15 sarana dalam kondisi rusak dan 82 sarana dalam kondisi yang layak. Dengan hasil tersebut maka ketersedian sarana dan prasarana PJOK pada SMA/SMK Negeri se-Kecamatan Pekutatan Kabupaten Jembrana masuk ke dalam kategori Cukup "C" dengan mendapatkan skor rata-rata sebesar 110. Ketersedian sarana dan prasarana yang cukup disekolah akan sangat berdampak terhadap minat, motivasi serta hasil belajar siswa. Sarana prasarana belajar yang lengkap yang dimiliki oleh pihak sekolah akan mendukung adanya variasi dalam pengajaran (Suranto, 2015). Sarana dan prasarana belajar ikut menentukan keberhasilan belajar siswa. Siswa yang memiliki sarana dan prasarana belajar baik, maka dalam belajarnya akan berjalan lancar dan teratur, sedangkan siswa yang belajar tanpa dibantu dengan sarana dan prasarana belajar yang baik, maka dia akan mendapatkan hambatan dalam menyelesaikan kegiatan belajar (Murtiningsih, 2017). Dengan ketersedian sarana dan prasarana proses belajar akan berlangusng dengan baik, siswa aktif dalam kegiatan belajar serta bisa mempraktekkan gerakan ataupun permainan olahraga yang dipelajari. Sarana dan prasarana yang tersedia akan membangkitkan semangat siswa untuk belajar karena mereka dapat belajar dengan langsung mencoba tidak hanya lewat metode ceramah oleh guru. Sarana dan prasarana menjadi bagian penting dalam mendukung pembelajaran, karena tanpa adanya sarana dan prasarana yang mendukung, maka proses pembelajaran tidak dapat berjalan secara optimal, oleh karena itu pengelolaan sarana dan prasarana sangat diperlukan untuk mewujudkan pembelajaran yang efektif.

Penelitian tentang ketersedian sarana dan prasarana selajan dengan beberapa penelitian sebelumnya yaitu: 1) penelitian oleh (Setiyoko\& Wisnu, 2019) yang menunjukkan ketersedian sarana dan prasarana berada pada kategori "B" dengan keterangan baik. Hal tersebut terbukti dengan alat dan lapangan yang digunakan cukup memadai dengan jumlah siswa yang tidak terlalu banyak, maka sarana dan prasarana di Kabupaten Pacitan sudah dikatakana baik pada tingkat sekolah menegah pertama, 2) penelitian oleh , (Saleh \& Ramdhani, 2020) menunjukkan bahwa kondisi sarana dan prasarana di sekolah 
SMP PGRI Barembeng, Gowa dikategorikan ideal dan menyatakan adanya pengaruh sarana prasarana terhadap kesegaran jasmani siswa. Implikasi penelitian ini adalah, sebagai bahan bagi maisng-masing sekolah untuk lebih mengenal lingkungan serta sarana belajar yang ada disekolah, membantu sekolah untuk mulai membenahi serta melengkapi sarana dan prasarana guna membantu proses pembelajaran untuk mencapai hasil belajar yang diharapkan.

\section{SIMPULAN DAN SARAN}

Berdasarkan hasil penelitian yang sudah dipaparkan di atas dapat disimpulkan bahwa ketersedian sarana dan prasarana PJOK pada SMA/SMK Negeri se-Kecamatan Pekutatan Kabupaten Jembrana masuk ke dalam kategori Cukup "C". Berdasarkan simpulan di atas, maka disarankan bagi guru PJOK, sekolah dan pemerintah untuk selalu memperhatikan dan juga melengkapi sarana dan prasarana secara berkelanjutan agar proses pembelajaran PJOK di sekolah dapat berjalan dengan optimal.

\section{DAFTAR RUJUKAN}

Anggriawan S., \&Fajar, B. D. (2018). Survei ketersediaan sarana dan prasarana pembelajaran pendidikan jasmani, olahraga dan kesehatan di sekolah smp se-kecamatan kebomas kab.gresik. Jurnal Pendidikan Olahraga Dan Kesehatan, 6(2), 266-270.

Arimbawa, I. G. A. A., Astra, I. K. B., \& Satyawan, I. M. (2017). Pengaruh Penerapan Model Pembelajaran Kooperatif Tipe STAD Berbantuan Media Gambar Terhadap Hasil Belajar Teknik Dasar Passing Sepak Bola. Jurnal Pendidikan Jasmani,Olahraga Dan Kesehatan Undiksha, 5(2), 1-9.

Asad, H. A., Mulyadi., \& Sugiharto, W. (2020). Survei sarana dan prasarana olahraga di smp negeri sekecamatan prabumulih timur. Jurnal Muara Olahraga, 3(1), 11-20. Retrieved from http://ejournal.stkip-mmb.ac.id/index.php/pjkr/article/view/335.

Bete, D. (2019). Ketrampilan guru pendidikan jasmani dalam mengatasi kekurangan sarana dan prasarana pembelajaran di smp. Jurnal Sport and Science, 2(1), 1-13.

Cahyati, N. N., \& Hariyanto, E. (2019). Survei sarana dan prasarana dalam pembelajaranpendidikan jasmani dan kesehatan di sekolah dasar negeri di kabupaten pasuruan. Gelanggang Pendidikan Jasmani Indonesia, 3(2), 111-120. Retrieved from http://journal2.um.ac.id/index.php/gpji/issue/view/716/showToc.

Dimyati \& Mudjiono. (2013). Belajar dan Pembelajaran. Jakarta: Rineka Cipta.157.

Hadi, S. F. D. K. (2013). Survei pendidikan jasmani, olahraga, dan kesehatan pada satuan pendidikan sd, smp, sma negeri se-kecamatan karangan kabupaten trenggalek.1(1), 64-69.

Hanggara A. S. D. (2019). Learning infrastructure facilities for physical education, sports and health public elementary schools. Jurnal Skripsi: Program Sarjana Universitas Negeri Semarang

Herlina \& Suherman, M. (2020). Potensi pembelajaran pendidikan jasmani olahraga dan kesehatan (pjok) di tengah pandemi corona virus disease (covid)-19 di sekolah dasar. Tadulako Journal Sport Sciences and Physical Education, 8(1), 1-7.

Herman, H., \& Riady, A. (2018). Survey sarana dan prasarana pendidikan jasmani di smp/ mts swasta kabupaten pangkep.SPORTIVE: Journal of Physical Education, Sport and Recreation, 1(2), 27. https: //doi.org/10.26858/sportive.v1i2.5624.

Indrawathi, N. L. P., Dewi, P. C. P., \& Widiantari, N. L. G. (2021). Faktor-faktor yang mempengaruhi hasil belajar pendidikan jasmani, olahraga dan kesehatan pada siswa kelas vii smp negeri 5 kuta selatan. Jurnal Pendidikan Kesehatan Rekreasi, 7(1). 239-247.

Junaedi, A., \& Wisnu, H. (2015). Survei tingkat kemajuan pendidikan jasmani, olahraga, dan kesehatan di sma dan ma negeri sekabupaten gresik. 3(3), 834-842.

Jordan. (2019). Survei sarana dan prasarana pendidikan jasmani olahraga dan kesehatan di sma negeri 9 bulukumba kabupaten bulukumba. Jurnal Skripsi: Universitas Negeri Makasar.

Khikmah, A. (2019). Survei sarana dan prasarana pendidikan jasmani di madrasah tsanawiyah (mts) sekecamatan klojen kota malang pada semester ganjil tahun 2017. Sport Science, 1(1), 12-19.

Mulya, G., \& Lengkana, A. S. (2020). Pengaruh kepercayaan diri, motivasi belajar terhadap prestasi belajar pendidikan jasmani. COMPETITOR: Jurnal Pendidikan Kepelatihan Olahraga, 12(2), 83. https://doi.org/10.26858/cjpko.v12i2.13781.

Murtiningsih. (2017). Pengaruh Motivasi Belajar, Sarana Belajar, Dan Percaya Diri Terhadap Hasil Belajar Ips Siswa Penerima Bsm (Bantuan Siswa Miskin) Smp Negeri Di Surabaya. Jurnal Ekonomi Pendidikan Dan Kewirausahaan, 5(2), 178-191. https://doi.org/10.26740/jepk.v5n2.p178-191.

Natal, Y. R., \& Bate, N. (2020). Manajemen pengelolaan saran dan prasarana pjok. Jurnal Altius: Jurnal Ilmu Olahraga dan Kesehatan, 9(2), 70-82. 
Nugraha, K. A., \& Nurharsono, T. (2020). Survei sarana dan prasarana pendidikan jasmani di kecamatan kedu kabupaten temanggung.Indonesian Journal for Physical Education and Sport, 1(2), 382-388. https://doi.org/10.4324/9780203135716-22.

Nopiyanto, Y., Raibowoa, S., Suryatama, R. Y., \& Ibrahim. (2020). Hambatan guru pendidikan jasmani generasi 80-an dalam pebelajaran daring di tengah pandemi covid-19. Jurnal Sporta Saintika, $5(2), 139-148$.

Nugraha,G.B.M. (2018).Pengembangan media pembelajaran pjok berbasis kartu gerak aktivitas pengembangan untuk siswa kelas xi sma negeri sukasada.

Nurjanah, V. L., \& Mulyana, N. (2019). Implementasi outdoor eucation terhadap motivasi belajar pendidikan jasmani. Journal of Physical Education and Sport Science, 3(1), 9-14.

Pasaribu, A. M. N., \& Mashuri, H. (2019). The role of rhythmic gymnastics for physical fitness for elementary school students. Jurnal SPORTIF : Jurnal Penelitian Pembelajaran, 5(1 SE- Article), 8997. https://doi.org/10.29407/js_unpgri.v5i1.12551.

Pambudi, M. I., Winarno, M. E., \& Dwiyogo, W. D. (2019). Perencanaan dan pelaksanaan pembelajaran pendidikan jasmani olahraga dan kesehatan. Jurnal Pendidikan: Teori, Penelitian dan Pengembangan, 4(1), 110-116.

Qoulbi, G. A., \& Alnedral. (2020). Pelaksanaan pembelajaran PJOK di kelas XII sma negeri 1 batusangkar dilihat dari sudut perencanaan, proses, dan evaluasi. Jurnal Patriot, 2(1), 148-158.

Risandy, L. A., Kusaini, H. M., \& Hamid, A. (2020). Analisis tingkat kebugaran jasmani ditinjau dari sarana dan prasarana pendidikan jasmani pada peserta didik sekolah menengah pertama negeri karang intan tahun 2019/2020.urnal Pendidikan Jasmani dan Olahraga,1(1), 1-7.

Saleh, M. S., \& Ramdhani, S. (2020). Survei sarana dan prasarana pendidikan jasmani dan tingkat kesegaran jasmani siswa kelas viii smp pgri barembeng kabupaten gowa.Journal Coaching Education Sports, 1(1), 49-62. https://doi.org/10.31599/jces.v1i1.86.

Satyawan, I. M. (2015). Survei sarana dan prasarana dalam pembelajaran penjasorkes di sma/smk/ma kabupaten buleleng tahun pelajaran 2014/2015.3(2), 54-67.

Setiyoko, H. (2019). Survei sarana dan prasarana pendidikan jasmani olahraga dan kesehatan di smp negeri se-kabupaten pacitan. Jurnal Pendidikan Olahraga Dan Kesehatan, 7(2), 345-348.

Sudibyo, N. A., \&Nugroho, R. A. (2020). Survei sarana dan prasarana pembelajaran pendidikan jasmani olahraga dan kesehatan pada sekolah menengah pertama di kabupaten pringsewu tahun 2019. Journal of Physical Education (JouPE), 1(1), 18-24.

Sugiarto, B. G. (2019). Pelaksanaan kegiatan belajar mengajar pendidikan jasmani di sekolah dasar inklusi. Jurnal Ilmu Keolahragaan,2(2), 138-155.

Suranto. (2015). Pengaruh Motivasi, Suasana Lingkungan Dan Sarana Prasarana Belajar Terhadap Prestasi Belajar Siswa (Studi Kasus Pada Sma Khusus Putri Sma Islam Diponegoro Surakarta. Jurnal Pendidikan Ilmu Sosial, 25(2), 11-19. https://doi.org/10.2317/jpis.v25i2.1532.

Wicaksono, G.H. (2019). Kreativitas guru penjas terhadap proses pembelajaran penjas di sekolah menengah pertama negeri sekecamatan kebumen kabupaten kebumen 2018. Jurnal Pendidikan Kesehatan Rekreasi, 5(2), 95-100.

Wiraguna, I. N., Lanang, I. G., Parwata, A., \& Semarayasa, I. K. (2020). Motivasi mengikuti pembelajaran pjok peserta didik sma di kecamatan bangli dalam pembelajaran daring. Jurnal Ilmu Keolahragaan Unidksha,8, 185-194.

Yusuf, J. (2016). Survei tingkat kemajuan pendidikan jasmani, olahraga, dan kesehatandi sekolah menengah atas (sma) negeri se-kabupaten bangkalan. Jurnal Pendidikan Olahraga Dan Kesehatan, $4(1)$. 